\title{
Topographic Map Analysis of High Elevation Black Hills Through Valleys Linking Spearfish and Rapid Creek Headwaters Valleys, Lawrence County, South Dakota, USA
}

\author{
Eric Clausen ${ }^{1}$ \\ ${ }^{1}$ Independent researcher, Jenkintown, PA, USA \\ Correspondence: Eric Clausen, Independent researcher, Jenkintown, PA, USA. E-mail: eric2clausen@gmail.com
}

Received: November 28, 2017

Accepted: December 8, 2017 Online Published: December 20, 2017

doi:10.5539/jgg.v10n1p8

URL: http://dx.doi.org/10.5539/jgg.v10n1p8

\begin{abstract}
The Spearfish-Rapid Creek drainage extends from elevations greater than 7130 feet (2173 meters) roughly in a north direction across the northern Black Hills upland to where it becomes the Spearfish-Whitewood Creek drainage divide at an elevation of approximately 6440 feet (1963 meters) and separates north-oriented Spearfish Creek headwaters from southeast- and east-oriented Rapid Creek headwaters. This study used detailed topographic maps to investigate through valleys (and wind gaps) now crossing the Spearfish-Rapid Creek drainage divide, which is one of the Black Hills' highest drainage divides. Through valley (or wind gap) floor elevations were determined and ranged from approximately 6150 feet (1875 meters) to approximately 7050 feet (2149 meters) and through valley (and wind gap) depths were also calculated and ranged from approximately 30 feet ( 9 meters) to about 290 feet ( 88 meters). Map evidence suggesting these through valleys (and wind gaps) originated as components of diverging and converging complexes of bedrock-walled channels is described and suggests large and prolonged southeast-oriented floods once flowed from or across the Spearfish Creek drainage basin to the Rapid Creek drainage basin. Based on today's topography there is no upland Black Hills region capable of generating the large and prolonged floods required to erode the observed through valleys (and wind gaps) and their associated diverging and converging channel complexes so the erosion is interpreted to have taken place while the Black Hills were just beginning to emerge as the topographic high they are today. A water source could not be determined from map evidence, but large and prolonged southeast-oriented floods across the region are consistent with a recently proposed hypothesis that massive southeast-oriented (continental ice sheet) ice-marginal melt water floods eroded what are today western South Dakota and North Dakota river drainage basins.
\end{abstract}

Keywords: Crooks Tower, diverging and converging bedrock-walled valleys, drainage basin, drainage divide, wind gaps

\section{Introduction}

The term through valley is frequently used to describe former glacial melt water channels, although the term also can describe any water-eroded valley now crossed by one or more drainage divides. In many non-glaciated regions through valleys of the latter type are remarkably common and provide evidence of now dismembered stream or river drainage routes. The dismemberment of those former drainage routes and the through valley formation process almost always involved one or more stream capture events, yet Bishop (1995) argues stream capture is rare in normal drainage net evolution. If Bishop is correct, then through valleys provide evidence of unusual drainage and/or other geologic events. The study reported here analyzes detailed topographic map evidence to determine the nature of drainage routes responsible for through valleys (and wind gaps) that now cross Black Hills upland regions and that link the present day Spearfish Creek drainage basin with the modern day Rapid Creek drainage basin.

Figure 1 shows the Black Hills location along the South Dakota-Wyoming border and the Cheyenne and Belle Fourche River drainage routes (C and B in figure 1), which almost completely encircle the uplift area. Rapid Creek (R) is an east-oriented Cheyenne River tributary and Spearfish Creek (S) is a north-oriented Belle Fourche River tributary. Rapid and Spearfish Creeks both have headwaters in the western Limestone Plateau area at elevations exceeding 7000 feet (2134 meters), although Rapid Creek flows in a generally east direction across 
the central core area before descending from the uplifted core area in a deep canyon (known as the Dark Canyon) to join the Cheyenne River at an elevation of less than 2440 feet (744 meters). Spearfish Creek descends from the Limestone Plateau area also in a deep canyon and joins a Belle Fourche River tributary (the Redwater River) at an elevation of approximately 3220 feet (981 meters), which then joins the Belle Fourche River at an elevation of slightly less than 3000 feet (914 meters). Several well defined through valleys and wind gaps with floor elevations greater than 6000 feet (1829 meters) link valleys of streams now flowing to Spearfish Creek with valleys of streams flowing to Rapid Creek. Water flowing from or across the present day Spearfish Creek drainage basin to the present day Rapid Creek drainage basin (or vice versus) must have eroded the through valleys and wind gaps. The question asked here is "what type of drainage system eroded these high elevation through valleys and wind gaps and how and why was that earlier drainage system dismembered?"

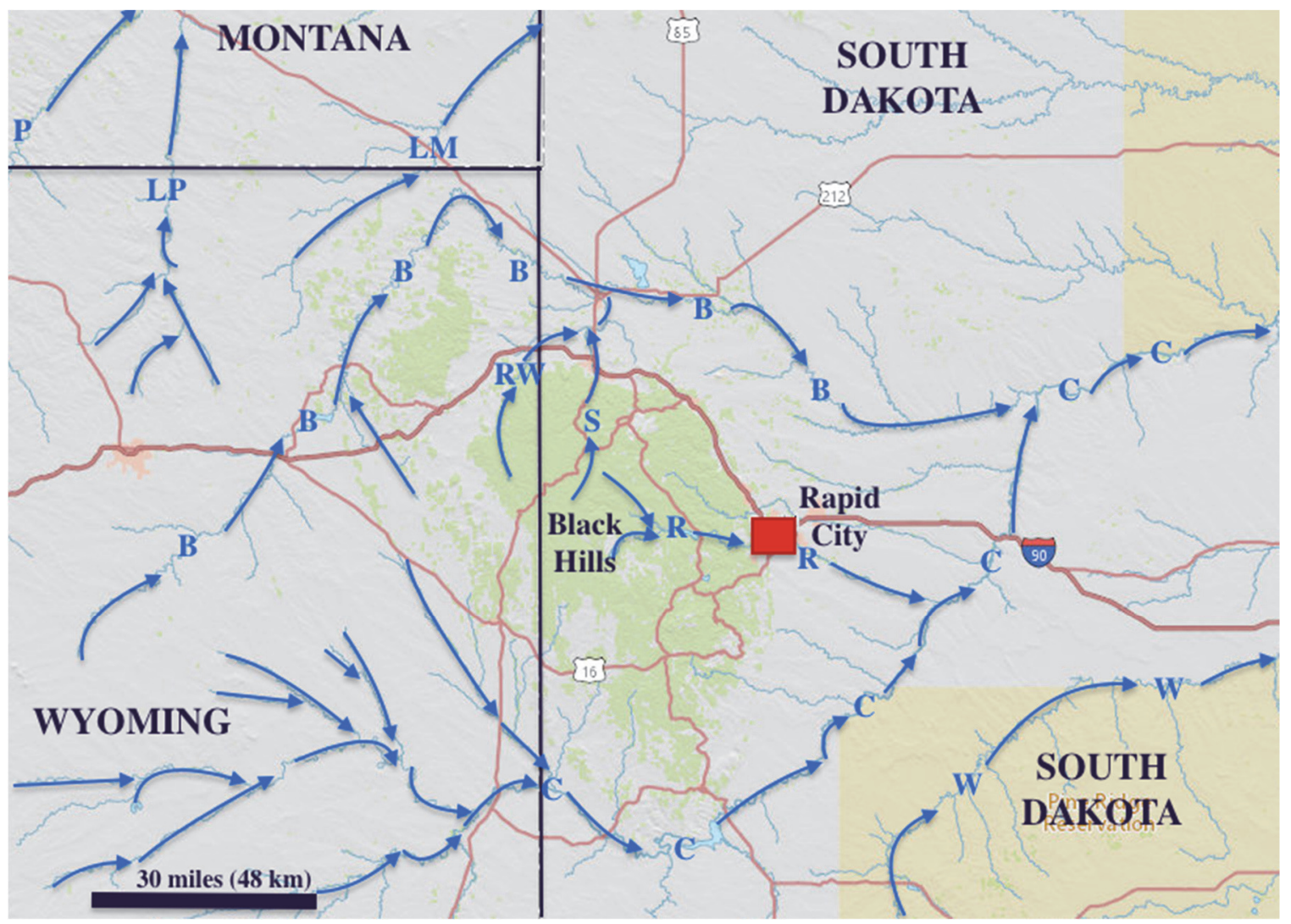

Figure 1. Modified map from United States Geological Survey (USGS) National Map website showing the Black Hills location west of Rapid City. Blue arrows and letters identify drainage routes as follows: "B" Bell Fourche

River, "C" Cheyenne River, "LM" Little Missouri River, "LP" Little Powder River, "P" Powder River, "R"

Rapid Creek, "RW" Redwater River, "S" Spearfish Creek, and "W" White River

Thornbury (1965) describes the Black Hills as an elliptical shaped uplift elongated in a northwest to southeast direction approximately 125 miles (201 kilometers) long and 65 miles (105 kilometers) wide. Central uplift areas are more than 2500 feet (762 meters) above the surrounding plains and suggest uplift of approximately 9000 feet (2743 meters) has occurred. Thornbury continues by identifying distinctive regions: "(a) a central core of granite and metamorphic rocks, (b) a limestone plateau that encircles the central core, (c) the Red Valley, which nearly encloses the Black Hills, but is most strikingly developed on the east side, (d) a hogback ridge just outside the Red Valley, and (e) a belt of small laccolithic peaks at the north edge of the uplift." Through valleys discussed here are located in the central core, which according to Thornbury "consists of a complex of Precambrian granites, schists, and metasedimentaries" and in the Limestone Plateau, which "is underlain mainly by limestones of Paleozoic age." Thornbury also notes "the Limestone Plateau is much wider on the west than it is on the east side of the uplift. On the west it is 15 to 20 miles [24 to 32 kilometers] wide and has the characteristics of a cuesta with an infacing scarp, but on the east, where dips are much steeper, instead of a cuesta it forms a homoclinal ridge." 


\section{Previous Work}

Darton (1909) provided one of the earliest comprehensive descriptions of the northern Black Hills region geology. In that report Darton observes, "The central area of the Black Hills comprises an elevated basin, eroded in crystalline schists and granite, in which scattered rocky ridges and groups of mountains are interspersed with park-like valleys. The wider valleys are above the heads of canyons of greater or less size, which become deeper and steeper sided as they extend outward to the northeast, east, and south." Darton continues by saying, "The limestone plateau forms an interior highland rim around the central area, rising considerably above the greater part of the region of crystalline rocks.... Streams, which flow down [the limestone plateau's] ...slope rise in shallow, park-like valleys in the plateau and sink into deep canyons with precipitous walls of limestone, locally many hundreds of feet [meters] high. The most notable of these canyons is that of Spearfish Creek [which flows to the Belle Fourche River].... The [limestone] plateau... swings around to the eastern side of the hills, where owing to the greater dip of the strata, it narrows to a ridge having a steep western face. This ridge is intersected by the water gaps of all the larger streams [including Rapid Creek that] ...rise in the high limestone plateau on the west, cross the region of crystalline rocks, and flow through canyons in the flanking regions on the eastern side to the Cheyenne River."

While not addressing details Darton (1909) does provide some Black Hills region erosion ideas. "The Black Hills dome developed early in the Tertiary time-or possibly in latest Cretaceous time-to a moderate height, and the larger topographic outlines of the region were established before the Oligocene epoch, the dome being truncated and its larger old valleys excavated in part to their present depths.... This is shown by the occurrence in them of White River (Oligocene) deposits, even in some of their deeper portions. Where the great mass of eroded materials was carried is not known.... Oligocene deposits were laid down by streams and in local lakes or bayous and finally covered the country to a level now far up the flanks of the Black Hills. Erosion has removed them from most of the higher regions [but with outliers at elevations exceeding 5200 feet or 1585 meters]... In many places on the slopes of the uplift there is clear evidence of superposition of drainage, due to the former capping of Oligocene formations.... After the Oligocene the Black Hills dome was raised several hundred feet and was more extensively eroded."

Since Darton's publication most work related to Black Hills erosion history has focused on study of the surrounding region's alluviual deposits, especially in the region to the east of the Black Hills. For example Wanless (1923) used coarse-grained sediments found in the Oligocene White River deposits located east of the Black Hills to suggest the Black Hills uplift caused greater rainfall in the uplifted area and greater aridity in the plains to the east. He also describes a later Upper Tertiary time period when streams flowing from the Black Hills "possessed great power both of erosion and transportation, as they moved pebbles and small boulders from the pre-Cambrian core of the Black Hills fifty to eighty miles [80 to 129 kilometers] out on the plains, where they are found in the White River valley.... Many of these pebbles have diameters of 8 inches to a foot [20-30 centimeters], and all are stream worn and frequently chatter-marked."

Fillman (1929) associated terraces capping higher stream divides located east of the Black Hills with what she named the Mountain Meadow erosion surface (found in the central Black Hills core area) that was eroded during mid-Oligocene time. She interpreted the Mountain Meadow erosion surface area within the Black Hills interior basin to have been uplifted by 2000-3000 feet (610-914 meters) before Upper Oligocene time. The Mountain Meadow erosion surface as described by Fillman has a late mature topography with local relief of 1000 to 1500 feet (305 to 457 meters). Fillman also named lower elevation terraces east of the Black Hills as "Rapid" and "Sturgis", which she associated with Quaternary erosion and deposition. Plumley (1948) however states, "neither fossil nor physiographic evidence dates the Mountain Meadow surface as mid-Oligocene. Meyerhoff and Olmstead (1937) report that the sub-summit erosional surface in the Black Hills was formed contemporaneously with the Miocene depositional surface of the High Plains in southeastern Wyoming and Nebraska." Further Meyerhoff and Olmstead "conclude only that the true Mountain Meadow surface, as exemplified by the sub-summit surface within the Hills and the [Mountain Meadow terrace formed on the] Rapid-Boxelder Creek divide east of the Hills, was produced by degradation during Miocene to Pliocene time."

Providing additional Black Hills erosion history evidence Harksen (1966) described alluvium deposited by a former Black Hills drainage route named the Medicine Root River. The Medicine Root "gravels contain a high percentage of igneous and metamorphic rocks derived from the core of the Black Hills." Most alluvium is gravel although "all other size fractions from clay to boulders are present. Judging from the particle size, this stream was one of the most powerful in regards to carrying capacity that ever existed west of the Missouri River in South Dakota." The Medicine Root River drainage flowed "from the central Black Hills out across the Great Plains" and "was probably the major drainage of the southern Black Hills until the Cheyenne [River] captured 
the entire Black Hills drainage system.” Raymond et al (1976) provide a map showing Medicine Root gravel deposit locations, which extend in a southeast direction across the present day northeast-oriented White River valley and which they note are located 650 feet (198 meters) above today's White River. The map also shows the location of still higher elevation Thin Elk gravel deposits "described as remnants of an early Pliocene stream, which once extended from the Black Hills" in a southeast direction.

As early as 1902 Todd recognized headward erosion of the Cheyenne River captured southeast-oriented streams (including Rapid Creek) flowing from the Black Hills. Stamm et al (2013) based on work by Strafflin (1993) that dated volcanic ash deposits associated with the Medicine Root gravels inferred "that piracy by the Cheyenne River in the southern Black Hills occurred after 660 ka." In contrast Wanless (1923) reports that Todd (1902) suggested the capture "took place before the Pleistocene because of the amount of erosion since that time by the Cheyenne River", although Wanless suggests much of the regional erosion (east of the Black Hills) may have taken place before the capture, which he suggests may have been as late as Pleistocene and which was definitely after Middle Miocene. Zaprowski et al (2001) after studying regional stream longitudinal profiles believe the Cheyenne River captures of southeast-oriented streams such as Rapid Creek that now flow from the Black Hills occurred due to knickzone migration upstream from the Missouri River and "The Cheyenne River piracy demonstrates that a knickzone migration process has been active in the Black Hills for at least 600 k.y."

Clausen (2017a) using topographic map evidence suggested the large escarpment-surrounded Sage Creek and Scenic Basins were eroded as headcuts during a massive southeast-oriented flood flow event, and the headcuts were subsequently abandoned when headward erosion of the northeast-oriented Cheyenne River valley beheaded and captured the southeast-oriented flow. Clausen also proposed the same flood flow and erosion cycle eroded the White River valley, the Sage Creek and Scenic Basins, and the Cheyenne River valley, which probably occurred "in the late Cenozoic at a time when the southwest margin of a large North American ice sheet was nearby and immense volumes of melt water were flowing in a southeast direction along that continental ice sheet's southwest margin." In a subsequent paper Clausen (2017c) illustrated topographic evidence demonstrating that western South and North Dakota Missouri River tributary valleys had eroded headward in an identifiable sequence across what were probably immense southeast-oriented melt water floods flowing between the Black Hills uplift to the southwest and the ice sheet's southwest margin to the northeast. Further Clausen suggested the possibility that the north-oriented valleys were eroding headward across the ice-marginal melt water flood flow because the melting ice sheet had created and occupied a deep "hole" with space in that "hole" being opened up as the ice sheet melted.

\section{Research Method}

Through valleys linking the Spearfish Creek and Rapid Creek drainage basins were first noticed during the much larger and unpublished Missouri River drainage basin landform origins research project. That multi-year project consisted of systematically studying detailed United States Geologic Survey (USGS) topographic maps of the entire Missouri River drainage basin and adjacent drainage basins to determine how major drainage divides within and surrounding the large and complex Missouri River drainage basin originated. Drainage divide origins were determined by using divide crossings (through valleys, wind gaps, etc.) as evidence of previous drainage routes and then using barbed tributaries, elbows of capture, asymmetric drainage divides, abandoned headcuts, and similar evidence to determine how many thousands of capture events altered earlier drainage routes so as to produce the present day Missouri River drainage basin drainage routes. Approximately 550 unpublished and detailed project essays (or research notes) can be found in blog format at the geomorphologyresearch.com website.

Research related to this paper used detailed topographic maps found at the United States Geological Survey (USGS) National Map website to identify through valleys and wind gaps linking the Spearfish Creek and Rapid Creek drainage basins. The most obvious through valleys and wind gaps were identified and their floor elevations and depths determined. Other through valleys and wind gaps crossing the drainage divide were also observed, but were considered to be duplicative or less convincing as evidence. Geological maps (e.g. Darton, 1909 and Martin et al, 2004) were studied to determine if geologic factors could account for the through valley and wind gap locations. Because no evidence was found to believe otherwise each of the identified through valleys and wind gaps was interpreted to have been eroded by water flowing across the Spearfish-Rapid Creek drainage divide in one direction or the other.

Several lines of reasoning were used to determine the flow moved from or across the present day Spearfish Creek drainage basin to the Rapid Creek drainage basin. First, there are no reports of large quantities of Black Hills metamorphic and granite alluvium found in the Spearfish Creek drainage basin, which would be expected 
had flow been in the opposite direction. Second, literature reports and personal field observations suggest powerful streams flowing in an east or southeast direction carried coarse-grained Black Hills crystalline core debris eastward onto the plains, suggesting water probably flowed in an east direction across the Spearfish-Rapid Creek drainage divide. Third, valley orientations are easier to explain if streams crossing the Spearfish-Rapid Creek drainage divide converged in the Rapid Creek valley rather than in the Spearfish Creek valley.

Map evidence also suggested through valleys and wind gaps now crossing the Spearfish-Rapid Creek drainage divide once were components of diverging and converging bedrock-walled stream channels. Since the Spearfish-Rapid Creek drainage divide and the Spearfish Creek headwaters drainage basin is today located on limestone bedrock map evidence was checked to determine if diverging and converging channel complexes also existed in the higher elevation area of the Rapid Creek drainage basin, much of which is underlain by crystalline metamorphic and granite bedrock. It was determined that the Black Hills upland region diverging and converging channel complexes are not bedrock related and then based on literature interpretations it was determined that bedrock-walled diverging and converging channel complexes form during large flood events when water overwhelms existing drainage systems and spills across drainage divides. Since today the divide between Spearfish and Rapid Creeks is one the Black Hills' highest drainage divides there is no upland Black Hills region where such large floods could originate. For that reason it was determined the through valleys and wind gaps now crossing the Spearfish-Rapid Creek drainage divide and their associated diverging and converging channel complexes must have been eroded by large and prolonged southeast-oriented floods at a time when the Black Hills dome was just beginning to emerge as a high topographic feature above the surrounding plains.

\section{Results}

\subsection{East Spearfish-North Fork Rapid Creek divide: Northern Segment}

The deepest through valley crossing the Spearfish-Rapid Creek drainage divide is seen in figure 2 where red numbers identify the most obvious through valley locations. Through valley number 1 links southeast-oriented North Fork Rapid Creek with northwest-oriented East Spearfish Creek and has a floor elevation of between 6140 and 6160 feet (1871 and 1878 meters). Elevations north of the through valley rise to more than 6440 feet (1963 meters) while to the south elevations rise to more than 6500 feet (1981 meters) suggesting the bedrock-walled through valley is approximately 290 feet (88 meters) deep. Southeast-oriented water flowing from the present day Spearfish Creek drainage basin to the North Fork Rapid Creek valley eroded through valley 1 and a reversal of flow created what is today northwest-oriented East Spearfish Creek and also created the present day East Spearfish-North Rapid Creek drainage divide.

Through valley 2 does not cross the Spearfish-Rapid Creek drainage divide, but does provide insights into the nature of the stream or river that eroded through valley 1 . Through valley 2 has a floor elevation of between 6160 and 6180 feet (1878 and 1884 meters), only slightly higher than through valley 1 , and suggests the southeast-oriented water that eroded through valley 1 flowed in diverging and converging bedrock-walled channels. A similar through valley just to the northwest of figure 2 with a floor elevation of between 6040 and 6060 feet (1841 and 1847 meters) further indicates southeast-oriented water flowing to through valley 1 moved in diverging and converging bedrock-walled channels. However, the floor elevation of the through valley (northwest of figure 2) is lower than the floor elevation of through valley 1, which may be the result of crustal warping. If so crustal warping may have been raising the Black Hills while southeast-oriented water was flowing across the region, which may account for the flow direction reversal and for the creation of the drainage divide between East Spearfish and North Fork Rapid Creeks. Through valley H links the North Fork Rapid Creek valley with the north-oriented Whitewood Creek valley, which like the Spearfish Creek valley drains in a north direction to the Belle Fourche River.

Through valleys 3 and 4 both have floor elevations of between 6420 and 6440 feet (1957 and 1963 meters) and suggest initially southeast-oriented flow moving along today's East Spearfish Creek alignment diverged into several separate streams before converging again in the North Fork Rapid Creek valley. Ridges on either side of through valleys 3 and 4 rise to more than 6570 feet (2003 meters), which today is higher than elevations of ridges surrounding through valley 1 . Through valleys 3 and 4 could not have been eroded when the floor of through valley 1 was more than 500 feet (152 meters) deeper than the ridge through valleys 3 and 4 now cross. Probably the diverging and converging southeast-oriented streams of water at first flowed across a fairly level ridge when through valleys 1,3 , and 4 were initiated. The lower ridge elevations now surrounding through valley 1 may be the result of deeper erosion along and near that channel and/or of crustal warping that raised figure 1 southern areas relative to figure 1 northern areas. Such crustal warping, if it occurred as diverging and 
converging streams of water flowed in through valleys 1,3 , and 4 , would have given through valley 1 an advantage enabling through valley 1 to capture all of the flow and causing through valleys 3 and 4 to be abandoned.

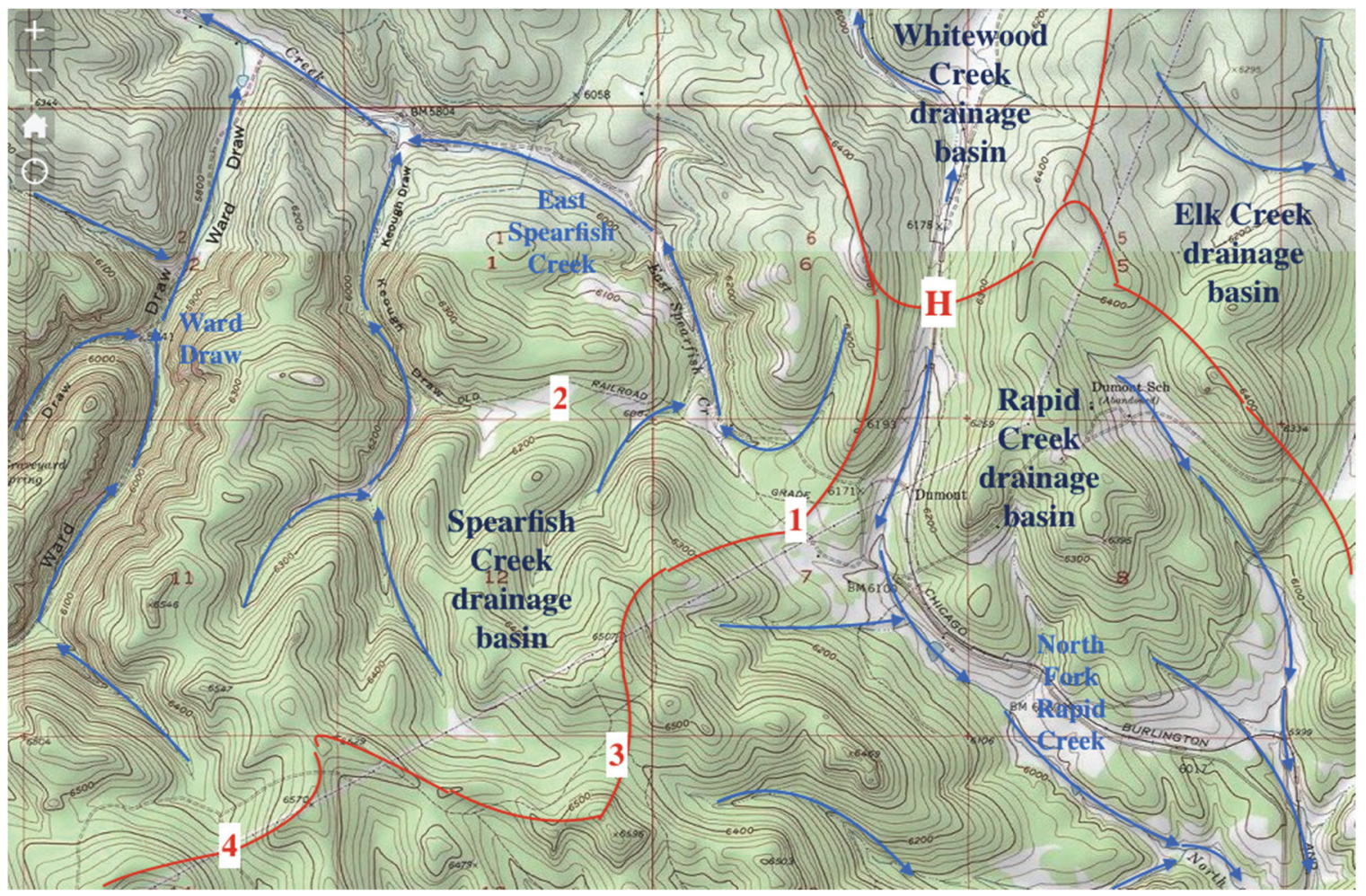

Figure 2. Modified topographic map from the USGS National Map website showing East Spearfish Creek and North Fork Rapid Creek headwaters areas. Red lines follow drainage divides and blue arrows show streams and flow directions. Red numbers identify through valleys discussed in the text. Sides of squares in the red grid are 1 mile (1.6 kilometers) in length and the contour interval is 20 feet (6 meters)

\subsection{Through Valleys Leading to Tillson Creek}

Tillson Creek is a southeast-, east-, and southeast-oriented stream draining to east-oriented Swede Gulch, which then drains to a south-oriented North Fork Rapid Creek segment. Figure 3 illustrates through valleys 5, 6, 7, 8, and 9, which cross the Spearfish-Rapid Creek drainage divide to reach Tillson Creek and shows their relationship to through valley 4 . Through valley 5 , like through valley 4 , is approximately 100 feet (30.5 meters) deep and links a northwest-oriented valley draining to north-oriented Ward Draw (and then to northwest-oriented East Spearfish Creek) with a southeast-oriented valley leading to Tillson Creek and has a floor elevation of between 6520 and 6540 feet (1987 and 1993 meters). Through valley 6 links the same northwest-oriented valley leading to Ward Draw (as through valley 5) and a different north-oriented valley leading to Ward Draw with a different south-southeast oriented valley leading to Tillson Creek and has a higher floor elevation of between 6540 and 6560 feet (1993 and 2000 meters). Through valley 7 links a north-oriented valley leading to Ward Draw with a south-oriented valley leading to Tillson Creek and has a floor elevation of between 6520 and 6540 feet (1987 and 1993 meters). Through valley 8 is different in that it links a northwest- and west-oriented valley leading to north-oriented Spearfish Creek and has a floor elevation of between 6580 and 6600 feet (2006 and 2012 meters). Through valley 9 links a north-oriented valley leading to a west-oriented valley leading to north-oriented Spearfish Creek and has a floor elevation of between 6620 and 6640 feet (2018 and 2024 meters). 


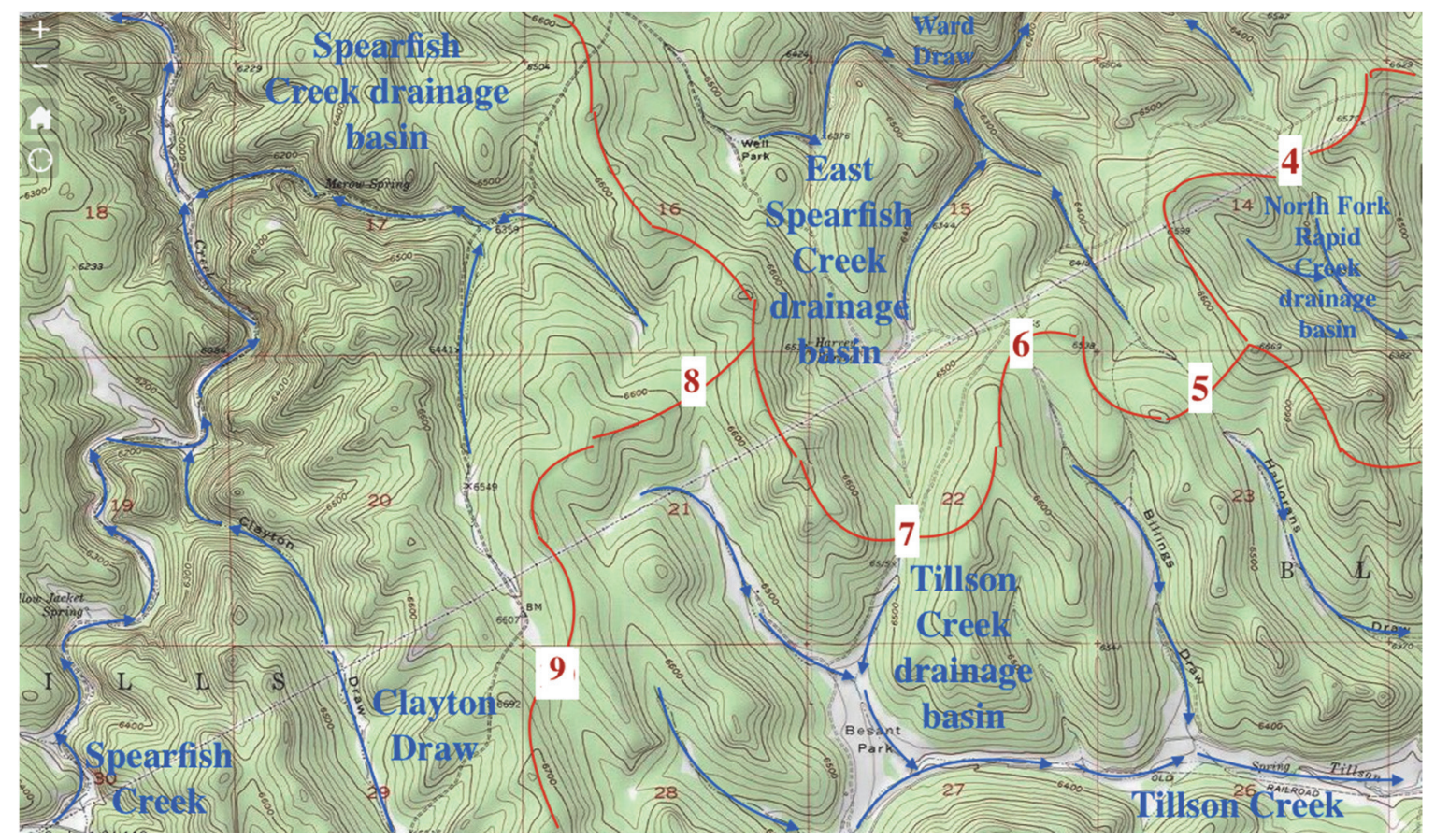

Figure 3. Modified topographic map from USGS National Map website showing through valleys leading from Spearfish Creek drainage basin to Tillson Creek drainage basin. Squares defined by faint red grid have sides that are 1 mile (1.6 kilometers) in length. The contour interval is 20 feet ( 6 meters)

Diverging and converging streams of water flowing from the Ward Draw (East Spearfish Creek) drainage basin to the Tillson Creek (North Fork Rapid Creek) drainage basin probably eroded through valleys 5, 6, and 7 while diverging and converging streams of water flowing from the Spearfish Creek drainage basin to the Tillson Creek drainage basin probably eroded through valleys 8 and 9 . If so flow directions along the present day north-oriented Ward Draw alignment and north-oriented Spearfish Creek alignment have been reversed. The alternate hypothesis is a reversal of flow along the Tillson Creek alignment, which would require a reversal of flow along the modern day North Fork Rapid Creek and Rapid Creek alignments, which seems even more implausible than a reversal of flow along today's Spearfish Creek alignment. Interestingly this is one of the highest regions in the western Black Hills Limestone Plateau with a very small area of slightly higher elevations to the south (partially seen in figures 4 and 5). Based on today's elevations there is no source area capable of generating enough water to simultaneously erode the multiple through valleys seen today, which the similarity of through valley floor elevations suggests must have been how the through valleys seen in figure 3 were eroded.

\subsection{Valleys Leading to the South Fork Rapid Creek North of Crooks Tower}

Crooks Tower (located near the south center edge of figure 4) has an elevation of 7137 feet (2175 meters) and is the highest point in the western Black Hills and in the Spearfish Creek and Rapid Creek drainage basins (it is at the north end of a high ridge better seen in figure 5). The drainage divide between Spearfish and Rapid Creeks extends in a south-to-north direction across Crooks Tower and then turns in a northeast direction to through valleys (or wind gaps) 12 and 10. Through valley (or wind gap) 10 links north-northwest oriented Clayton Draw and a west-northwest oriented Spearfish Creek tributary valley with a southeast- and south-oriented valley draining to the South Fork Rapid Creek and has a floor elevation of between 6600 and 6620 feet (2012 and 2018 meters). Through valley (or wind gap) 12 is higher and links the valley of a north- and west-oriented Spearfish Creek headwaters stream with the South Fork Rapid Creek headwaters and has a floor elevation of between 6720 and 6740 feet (2048 and 2054 meters). Through valleys (or wind gaps) 10 and 12 were most likely eroded by diverging and converging southeast-oriented streams of water moving from the Spearfish Creek alignment to the South Fork Rapid Creek.

Through valley 11 with a floor elevation of between 6500 and 6520 feet (1981 and 1987 meters) is much deeper than through valleys (or wind gaps) 10 and 12 and was eroded by the diverging south-oriented streams of water flowing across through valleys 7 and 8 and then converging in what is today the Tillson Creek headwaters area 
and that once flowed to the South Fork Rapid Creek. Headward erosion of the east-, southeast-, and east-oriented Tillson Creek valley captured water moving in through valleys 7 and 8 and diverted that flow to the North Fork Rapid Creek valley and ended flow to through valley 11 . What is puzzling about through valleys $7,8,9,10,11$, and 12 is they all appear to have been eroded by diverging and converging streams of water flowing from what is today the north-oriented Spearfish Creek drainage basin and that water initially flowed across what is today one the Black Hills' highest ridges. The diverging and converging valleys suggest water volumes that eroded them were large. Further one or more stream captures were required to create each of the drainage divides now crossing each of the through valleys. As seen in figures 4 and 5 there is no source area where such large volumes of water could originate.

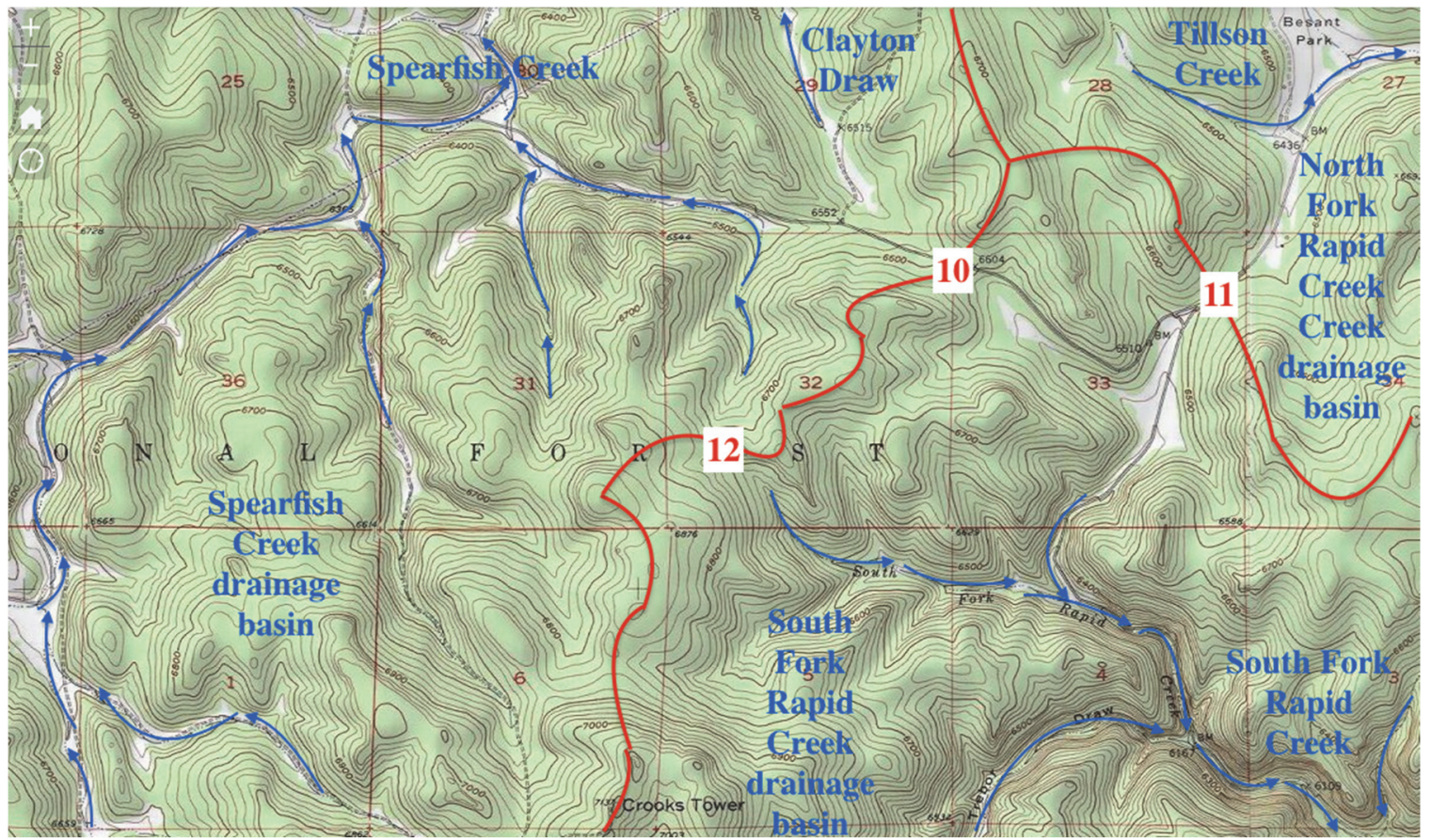

Figure 4. Modified topographic map from the USGS National Map website showing the Spearfish Creek-South Fork Rapid Creek drainage divide area north of Crooks Tower (seen near south center edge). Sides of squares in the red grid are 1 mile (1.6 kilometer) in length and the contour interval is 20 feet (6 meters)

\subsection{Valleys Leading to the South Fork Rapid Creek South of Crooks Tower}

Crooks Tower (elevation 7137 feet or 2175 meters) is at the north end of a limestone ridge that separates Spearfish Creek headwaters areas from South Fork Rapid Creek headwaters areas as seen in figure 5. South and west of the Spearfish Creek headwaters are Cold Springs Creek headwaters. The letters "A" and "B" identify north-to-south oriented through valleys linking north-oriented Spearfish Creek headwaters valleys with south and west-oriented Cold Springs Creek headwaters valleys and suggest water once flowed between the Spearfish Creek drainage basin and (and maybe across) the Cold Springs Creek headwaters region. Cold Springs Creek is a major northwest- and north-oriented Redwater River tributary with water eventually converging with Spearfish Creek and emptying into the Belle Fourche River (see figure 1).

Two through valleys or wind gaps (numbers 13 and 14) cross the high north-to-south oriented limestone ridge on which Crooks Tower is located with ridge elevations in section 18 (south of through valley or wind gap 14) rising to 7130 feet (2173 meters) or almost as high as Crooks Tower to the north. Through valley or wind gap 13 links Spearfish Creek headwaters valleys with a South Fork Rapid Creek tributary valley and has a floor elevation of between 6960 and 6980 feet (2121 and 2128 meters) and through valley or wind gap 14 links a somewhat different set of Spearfish Creek headwaters valleys with the same South Fork Rapid Creek tributary valley and has a floor elevation of 7000 and 7020 feet (2134 and 2140 meters). The similarity of elevations suggests diverging and converging streams eroded the two deep valley remnants across what is today one the Black Hills' highest ridges, but based on today's topography there is no visible water source. 


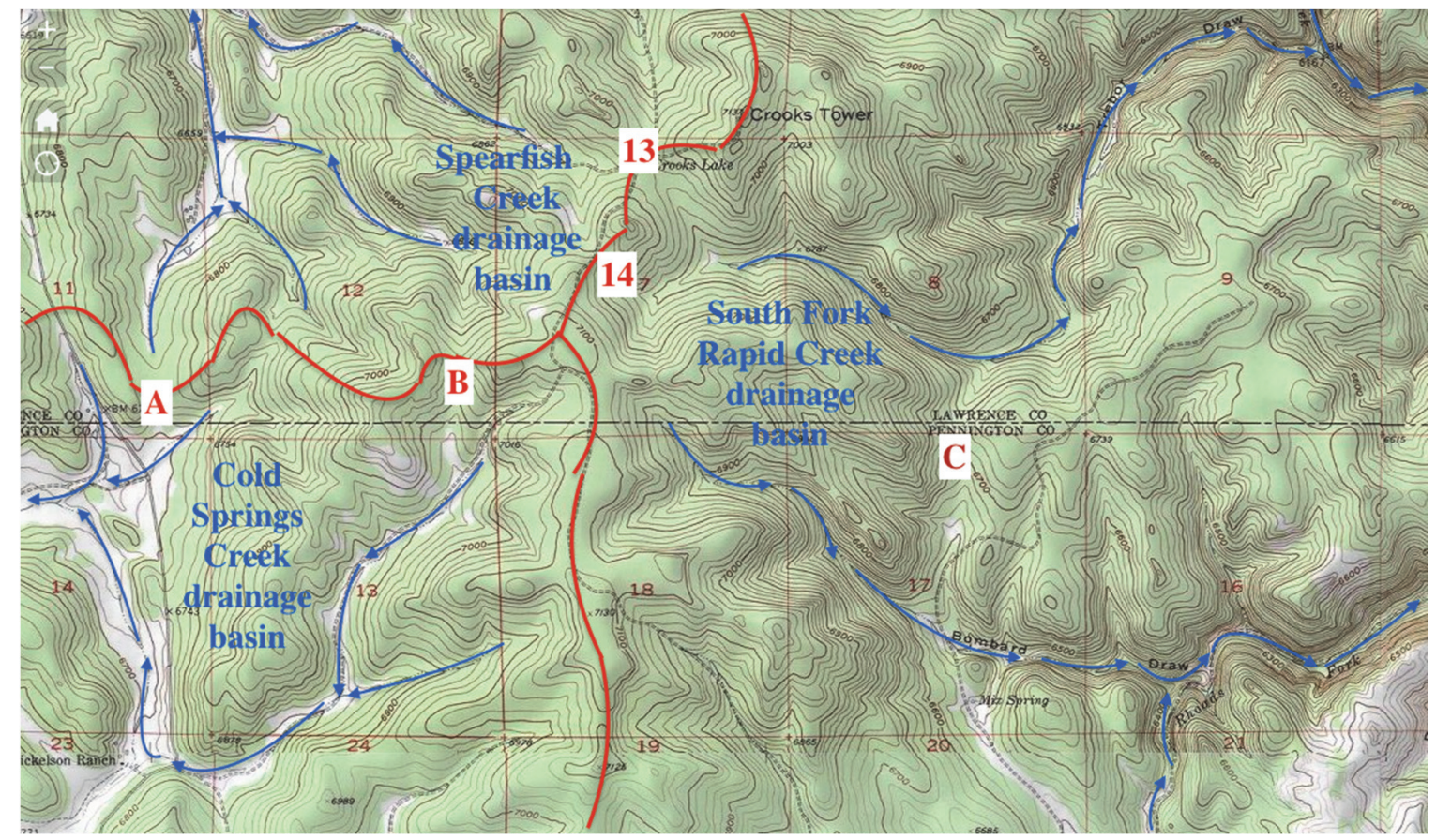

Figure 5. Modified map from USGS National Map website showing the Spearfish-South Fork Rapid Creek drainage divide area south of Crooks Tower. Squares in the faint red grid have sides that are 1-mile (1.6 kilometer) in length and the contour interval is 20 feet (6 meters).

\subsection{Spearfish Creek-Rapid Creek Drainage Divide Characteristics}

The Spearfish-Rapid Creek drainage divide is a segment of the longer drainage divide between north-oriented drainage to the Belle Fourche River and east-oriented drainage to the Cheyenne River (see figure 1) and extends in roughly a south-to-north direction from the Crooks Tower area across the northern Black Hills to the region seen in figure 2 where the Belle Fourche River-Cheyenne River drainage divide becomes the Whitewood-Elk Creek drainage divide. Crooks Tower is the highest point in Lawrence County (South Dakota), which includes most of the northern Black Hills with the Spearfish-Rapid Creek drainage divide being one of the Black Hills' highest drainage divides. Today elevations, with a local few exceptions, decrease in all directions from the Spearfish-Rapid Creek drainage divide. Table 1 shows approximate floor elevations of each of the above described through valleys or wind gaps and also the elevation of the highest contour line (or spot elevation) located north of each of the described through valleys or wind gaps, with the exception that the highest elevation south of through valley or wind gap 14 is shown. Maps used to identify the highest elevations used in table 1 had 20 -foot (6-meter) contour intervals so through valley floor elevations could vary by as much as 10 feet (3 meters) from numbers shown and actual high elevations could be as much as 20 feet (6 meters) higher than shown.

As seen in table 1 elevations along the Spearfish-Rapid Creek drainage divide decrease with a few exceptions from a high of 7137 feet (2175 meters) at Crooks Tower in the south to slightly more than 6440 feet (1963 meters) just south of through valley 1 . Likewise elevations of through valley floors, also with a few exceptions, decrease from a high of 7050 feet (2149 meters) at through valley or wind gap 14 to a low of 6150 feet (1875 meters) at through valley 1 . These decreases are consistent with the northward gradient of north-oriented Spearfish Creek, which must have captured the diverging and converging east-oriented streams of water that once flowed across the present day Spearfish-Rapid Creek drainage divide. However, based on today's topography it is not clear where the water originated or how streams of water could have flowed across a ridge defined by the high points shown in table 1, much less how headward erosion of the north-oriented Spearfish Creek valley was able to capture multiple streams of water some of which had eroded deep valleys across what is today a high drainage divide ridge. 
Table 1. Elevations of through valley or wind gap floors plus or minus 10 feet (3 meters) compared with valley depths plus or minus 20 feet ( 6 meters) and elevations of adjacent drainage divide segments. An asterisk indicates the valley does not cross the Spearfish-Rapid Creek divide, double asterisks indicate spot elevations were used, and a triple asterisk indicates the elevation was obtained south of the through valley

\begin{tabular}{|c|c|c|c|}
\hline $\begin{array}{l}\text { Through valley } \\
\text { number }\end{array}$ & $\begin{array}{l}\text { Valley floor elevation in } \\
\text { feet (meters) }\end{array}$ & $\begin{array}{l}\text { Approximate valley depth in } \\
\text { feet (meters) }\end{array}$ & $\begin{array}{l}\text { Highest contour line to north of } \\
\text { valley in feet (meters) }\end{array}$ \\
\hline 1 & $6150(1875)$ & $290(88)$ & $6440(1963)$ \\
\hline $2 *$ & $6170(1881)$ & $150(46)$ & $6320(1926)$ \\
\hline 3 & $6430(1960)$ & $130(40)$ & $6560(2000)$ \\
\hline 4 & $6430(1960)$ & $130(40)$ & $6570(2003)$ \\
\hline $5^{*}$ & 6530 (1990) & $120(37)$ & $6669(2033) * *$ \\
\hline 6 & 6550 (1996) & $80(24)$ & $6638(2023)^{* *}$ \\
\hline 7 & $6530(1990)$ & $90(27)$ & 6640 (2024) \\
\hline 8 & 6590 (2009) & $110(34)$ & $6720(2048)$ \\
\hline 9 & $6630(2021)$ & $30(9)$ & $6660(2030)$ \\
\hline 10 & $6610(2015)$ & $120(37)$ & $6740(2054)$ \\
\hline $11^{*}$ & 6510 (1984) & $190(58)$ & 6740 (2054) \\
\hline 12 & $6730(2051)$ & $40(12)$ & 6780 (2067) \\
\hline 13 & $6970(2125)$ & $150(46)$ & $7137(2175)^{* *}$ \\
\hline 14 & 7050 (2149) & $80(24)$ & $7130(2149)^{* * *}$ \\
\hline
\end{tabular}

Through valleys 1, 3, 4, 5, 6, and 7 diverge from the present day northwest-oriented East Spearfish Creek valley, yet today much of the East Spearfish Creek drainage basin is lower in elevation than the 6440 feet Spearfish-Rapid Creek drainage divide elevation north of through valley 1 and almost all of the East Spearfish Creek drainage basin is lower in elevation than elevations along the Spearfish-Rapid Creek drainage divide around through valleys 5, 6, and 7. How was water able to flow from what is today the East Spearfish Creek drainage basin to the Rapid Creek drainage basin? While each of the through valleys presents a perplexing problem, perhaps the through valleys or wind gaps most difficult to explain are numbers 13 and 14. Through valley or wind gap 13 with a depth of approximately 150 feet (46 meters) has been carved in limestone bedrock across what is today one of the highest ridges in the entire Black Hills. Yet one or more streams of water crossed that ridge and then were captured by headward erosion of even deeper Spearfish Creek headwaters valleys that were eroding headward into the limestone bedrock west of the present day high ridge.

\section{Discussion of the Water Source Problem}

Based on today's topography there is no area high enough and large enough to supply the water needed to erode the diverging and converging valleys now crossing the Spearfish-Rapid Creek drainage divide. While the Black Hills region does experience heavy precipitation events and a USGS South Dakota Water Science Center website lists many historic Black Hills region floods, some of which have caused loss of life and extensive property damage, those historic floods have occurred in downstream canyon valleys and at canyon mouths and not near the high altitude drainage divides such as the Spearfish-Rapid Creek drainage divide investigated here. Diverging and converging streams of water that came from somewhere must have eroded the through valleys and wind gaps described here, but today that somewhere does not exist.

The abandoned diverging and converging stream valleys while providing no clues as to the source of the water that eroded them do provide clues as to volumes of water needed to erode them. While this paper has focused on through valleys and wind gaps crossing the Spearfish-Rapid Creek drainage divide similar through valleys also cross drainage divides between many of the Spearfish Creek and Rapid Creek tributaries. Figure 6 illustrates the East Spearfish Creek drainage route downstream from figure 2 and shows through valleys linking the East Spearfish Creek valley with its various tributary valleys and also with the Spearfish Creek valley. While the diverging and converging valleys seen in figures 2-6 are eroded in a region of limestone bedrock somewhat similar through valleys are also carved in the metamorphic and granite bedrock underlying much of the higher elevation Rapid Creek drainage basin. 


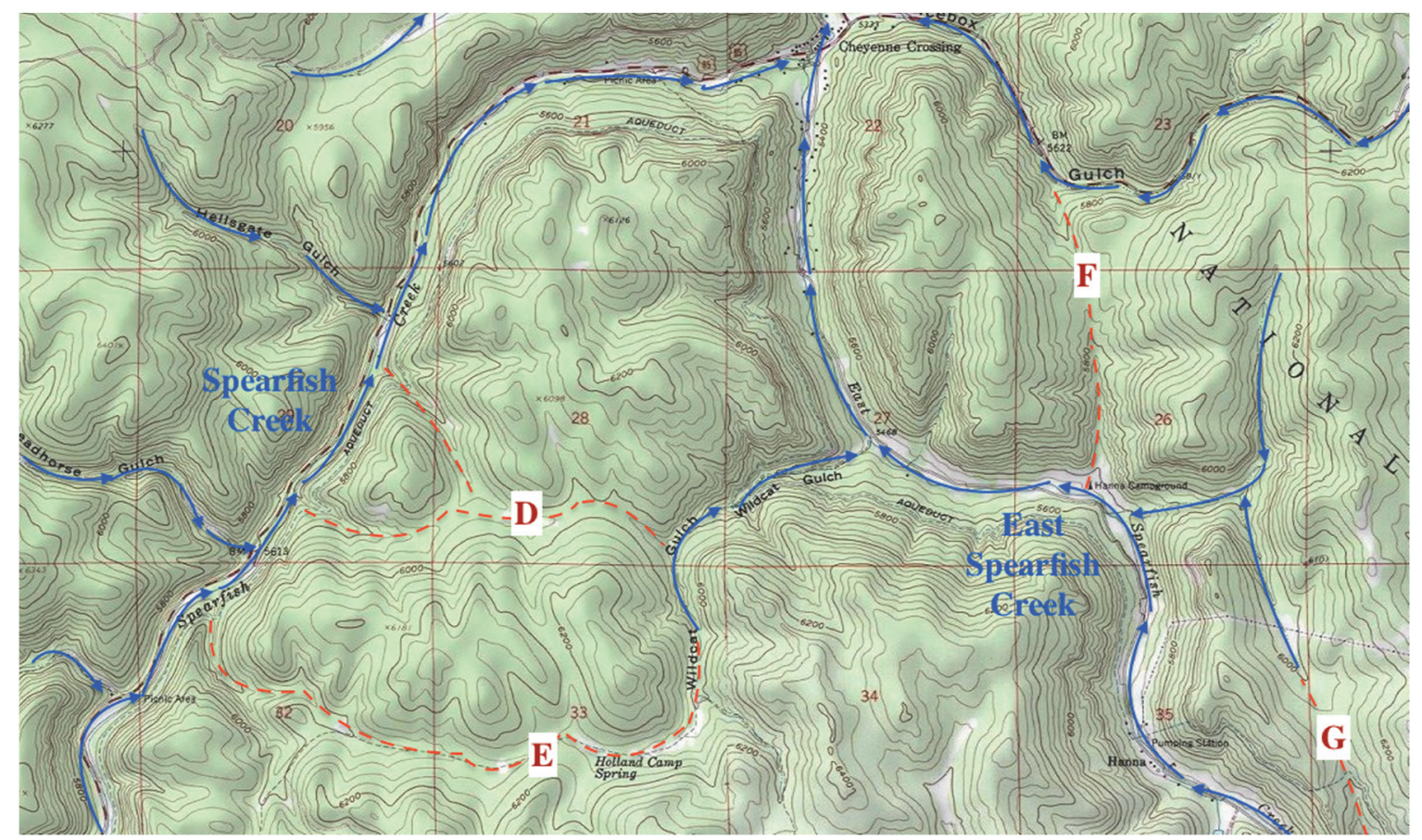

Figure 6. Modified topographic map from the USGS National Map website showing East Spearfish Creek drainage basin downstream from (or northwest of) figure 2. Dashed red lines and red numbers identify through valleys linking Spearfish Creek tributaries. Squares in the faint red grid have sides of 1 mile (1.6 kilometer) in length and the contour interval is 20 feet (6 meters).

What is significant about through valleys linking Spearfish and Rapid Creek tributaries is their floor elevations are almost always lower in elevation than nearby high points found along the Spearfish-Rapid Creek drainage divide. The floor of through valley D (in figure 6) has an elevation of between 5980 and 6000 feet (1823 and 1829 meters), the floor of through valley E an elevation of between 6160 and 6180 feet (1878 and 1884 meters), the floor of through valley F an elevation of 5840 and 5860 feet (1780 and 1786 meters), and the floor of through valley $\mathrm{G}$ an elevation of 6020 and 6040 feet (1835 and 1841 meters). Remember through valley 1, which links the northwest-oriented East Spearfish Creek valley with the southeast-oriented North Fork Rapid Creek valley has a floor elevation of between 6140 and 6160 feet (1871 and 1878 meters) and drainage divide elevations on either side of through valley 1 rise to more than 6440 feet (1963 meters). Similar networks of diverging and converging through valleys exist on either side of the Spearfish-Rapid Creek drainage divide, but are also almost always found at elevations lower than the Spearfish-Rapid Creek drainage divide elevations.

Perhaps the best-known example of bedrock-walled diverging and converging channels, although maybe on a larger scale, is found in the Channeled Scabland area of Washington State. Baker (1981) describes diverging and converging bedrock-walled valleys in the Channeled Scabland region of Washington State as having been eroded during a catastrophic flood event because the "pre-flood valleys did not have the capacity to convey the [Glacial Lake] Missoula flood discharges without spilling over pre-flood divides into adjacent valleys. This crossing of divides produces the effect of channels dividing and rejoining". Unlike the Channeled Scablands there is no identifiable water source that could have eroded the high altitude Black Hills networks of diverging and converging channels. Instead the Black Hills' bedrock-walled diverging and converging valleys are near the top of a dome with lower elevations in all directions. Diverging and converging valleys in what are today Black Hills upland regions must have been eroded by floodwaters before the Black Hills emerged as the high topographic feature that it is today.

Interpreting the through valleys now crossing the Spearfish Creek-Rapid Creek drainage divide to have been eroded during large flood events before the Black Hills emerged as a high topographic feature opens up explanations for some Spearfish-Rapid Creek drainage divide characteristics and also for possible water sources. Black Hills emergence was probably the result of two different processes one of which was the removal of easily eroded bedrock units surrounding the Black Hills as new river valleys eroded headward into and across the region. As previously noted Raymond et al (1976) reported Medicine Root River alluvium can be found high 
above the present day White River valley floor and the Thin Elk alluvium is located at even higher elevations. The Medicine Root alluvium and Thin Elk alluvium contain coarse-grained Black Hills rock debris carried by what Wanless (1923) and others have described as powerful streams that flowed across what are now the northeast-oriented Cheyenne and White River valleys (east of the Black Hills) and provide evidence that since the time of those powerful streams great thicknesses of sedimentary bedrock have been removed from the region located to the east of the Black Hills.

Tectonic uplift of the Black Hills domal structure is the other process that enabled the Black Hills to emerge. If large and prolonged southeast-oriented floods crossed the region while the tectonic uplift was beginning and before deep erosion had removed the surrounding bedrock the prolonged floods may have been able to cross the emerging Black Hills uplift region and may for a time have been able to erode the top of the rising dome as rapidly as the tectonic uplift occurred. If so the prolonged southeast-oriented floodwaters could account for the powerful streams reported by Wanless (1923) that carried coarse-grained Black Hills alluvium far out onto the plains and for the large volumes of water reported by Clausen (2017a) that enabled the northeast-oriented White and Cheyenne River valleys to erode headward in the region east of the Black Hills. Such a scenario not only accounts for multiple through valleys crossing the present day Spearfish-Rapid Creek drainage divide, but also for the networks of diverging and converging bedrock-walled valleys now found in the Black Hills upland regions. At some point the tectonic uplift began to proceed faster than the floodwaters could erode the rising dome core and caused floodwaters to be gradually channeled around the Black Hills uplift and to deeply erode the surrounding and more easily eroded sedimentary bedrock as the Black Hills dome continued to emerge.

The problem of where the large and prolonged southeast-oriented floods originated still remains. The Black Hills are located south and west of a well-recognized continental ice sheet margin and immense southeast-oriented ice-marginal melt water floods might explain the large and prolonged southeast-oriented floods that eroded the Black Hills upland through valleys and diverging and converging valley complexes, but Black Hills uplift is often thought to have occurred prior to North American continental ice sheets. In addition, today northeast-oriented rivers including the Powder River (see figure 1) flow across the region north and west of the Black Hills. There is considerable literature suggesting those rivers were once components of what has been referred to as pre-glacial northeast-oriented Bell River system that flowed across Canada to the Labrador Sea (see McMillan, 1973 or Sears, 2013). If those northeast-oriented rivers have existed since pre-glacial time they would have captured any southeast-oriented ice-marginal melt water floods and such floods would not have been able to reach the Black Hills region.

Expressing what is definitely a minority view White (1972) argued deep erosion by continental ice sheets should have destroyed Bell River system valleys, especially in areas of easily eroded bedrock found in North and South Dakota and adjacent Canada, although Sugden (1976) and others used the pre-glacial Bell River system of valleys and middle and late Tertiary sedimentary deposits to strongly oppose White's deep erosion by continental ice sheets hypothesis. While White's hypothesis has since received little support from subsequent researchers there has also been no explanation as to how the pre-glacial Bell River system of valleys survived the effects of continental ice sheet (and ice sheet melt water) erosion. The pre-glacial age for the Bell River system of valleys (in North and South Dakota and adjacent Canadian areas) is entrenched in the regional geologic literature, but until very recently has never been tested.

Clausen (2017b and 2017c) in that recent test presented evidence that western North and South Dakota river valleys, which are often associated with the pre-glacial Bell River system, eroded headward from a continental ice sheet location across immense southeast-oriented melt water floods. He argued the continental ice sheet had deeply eroded the underlying bedrock and created and occupied a deep "hole". The northeast-oriented valleys eroded headward from an ice-walled and bedrock-floored canyon that had detached the ice sheet's southwest margin and that had floor depths lower in elevation than the immense southeast-oriented ice-marginal floods moving just west and south of the detached ice sheet margin. As the detached ice sheet margin decayed northeast-oriented valleys eroded headward across that detached ice sheet margin and then across the large southeast-oriented melt water floods to form in an identifiable sequence what are today the western South and North Dakota White, Bad, Cheyenne, Moreau, Grand, Cannonball, Heart, Knife, and Little Missouri River drainage basins with the Powder River valley being eroded after erosion of the Little Missouri River valley. The large southeast-oriented floods that eroded the western North and South Dakota and adjacent area river valleys may explain how the through valleys and wind gaps now crossing the Spearfish-Rapid Creek drainage divide were eroded at a time when the Black Hills dome was beginning to emerge as a topographic high, although further work is needed. 


\section{Conclusions}

The Spearfish Creek-Rapid Creek drainage divide is today the highest drainage divide extending across the northern Black Hills uplands and is crossed by multiple through valleys (or wind gaps). Each of these through valleys and wind gaps is a water-eroded feature yet based on today's elevations no water source is apparent. Further, the through valleys and wind gaps appear to be components of diverging and converging bedrock-walled valley complexes that were probably eroded during large floods that overwhelmed then existing drainage systems with water spilling across drainage divides at multiple locations. These diverging and converging networks of bedrock-walled valleys are today at the top of a domal structure and are located more than 3000 feet (915 meters) above the surrounding plains. In addition the literature describes powerful east- and southeast-oriented streams that transported coarse-grained alluvium from the dome core far out onto the plains east of the Black Hills and then deeply eroded that entire eastern plains region.

Large and prolonged southeast-oriented floods provide the best explanation for the erosion of the through valleys and wind gaps now crossing the Spearfish-Rapid Creek drainage divide and their associated diverging and converging bedrock-walled valley complexes and also for coarse-grained Black Hills core alluvium found east of the Black Hills. If correctly interpreted those floods must have occurred as the Black Hills were just beginning to emerge above the surrounding plains and before tectonic uplift forced floodwaters to be channeled around the emerging Black Hills uplift. Floodwaters also deeply eroded the easy-to-erode bedrock surrounding the Black Hills uplift area. Assuming the northeast-oriented Bell River system of valleys is not pre-glacial in origin the large and prolonged floods could have been immense ice-marginal melt water floods flowing along the southwest margin of a continental ice sheet that had created and occupied a deep "hole". If so the through valleys and wind gaps crossing the Spearfish-Rapid Creek drainage divide provide evidence supportive of a deep erosion by continental ice sheets hypothesis and possible evidence of significant tectonic uplift associated with a nearby continental ice sheet.

\section{References}

Baker, V. R. (1981). Large-scale erosional and depositional features of the Channel Scabland: in Baker, V.R. ed., 1981, Catastrophic flooding; the origin of the channeled scabland. Dowden, Hutchinson and Ross, Inc. Stroudsburg, PA, 276-310.

Bishop, P. (1995). Drainage rearrangement by river capture, beheading and diversion. Progress in Physical Geography, 19(4), 449-473. https://doi.org/10.1177/030913339501900402

Clausen, E. (2017a). Solving a perplexing Scenic and Sage Creek drainage history problem, Pennington, County, South Dakota, USA. Journal of Geography and Geology, 9(2), 1-10. https://doi.org/10.5539/jgg.v9n2p1

Clausen, E. (2017b). Origin of Little Missouri River-South Fork Grand River and nearby drainage divides in Harding County, South Dakota and adjacent eastern Montana, USA. Open Journal of Geology, 7, 1063-1077. https://doi.org/10.4236/ojg.2017.78071

Clausen, E. (2017c). Using map interpretation techniques for relative dating to determine a western North Dakota and South Dakota drainage basin formation sequence, Missouri River drainage basin, USA. Journal of Geography and Geology, 9(4), 1-18. https://doi.org/10.5539/jgg.v9n4p1

Darton, N. R. (1909). Geology and water resources of the northern portion of the Black Hills and adjoining regions in South Dakota and Wyoming: United States Geological Survey Professional Paper, 65, 105 p.

Fillman, L. (1929). Cenozoic history of the. Black Hills: Iowa Studies in Natural History, 13, 1-48.

Harksen, J. C. (1966). The Pliocene-Pleistocene Medicine Root Gravel of Southwestern South Dakota. Bulletin of the Southern California Academy of Sciences, 65(4), 251-257. Also South Dakota Geological Survey reprint 6. Retrieved March 24, 2017, from http://www.sdgs.usd.edu/pubs/pdf/NR-09.pdf

Martin, J. E., Sawyer, J. F., Fahrenbach, M. D., Tomhave, D. W., \& Schulz, L. D. (2004). Geologic map of South Dakota. South Dakota Geologic Survey. Obtained from National Geologic Map Database. Retrieved March 21, 2017, from https://ngmdb.usgs.gov/Prodesc/proddesc_72317.htm

McMillan, J. N. (1973). Shelves of the Labrador Sea and Baffin Bay, Canada. Canadian Society of Petroleum Geologists Memoir, 1, 473-515.

Meyerhoff, H. A., \& Olmstead, E.W. (1937). Cenozoic leveling in the Black Hills (abstract): Pan-Am Geologist, $68,306$.

Plumley, W. J. (1948). Black Hills terrace gravels: a study in sediment transport. The Journal of Geology, 56(6) 
526-577. https://doi.org/10.1086/625559

Raymond, W. H., King, R. U., \& Gries, J. P. (1976). Status of mineral resource information for the Pine Ridge Indian Reservation, South Dakota. Bureau of Indian Administration Administrative Report BIA-12, 1-31. Retrieved March 27, 2017, from http://citeseerx.ist.psu.edu/viewdoc/download?doi=10.1.1.552.6081\&rep=rep1\&type $=$ pdf

Sears, J. W. (2013). Late Oligocene-early Miocene Grand Canyon: A Canadian connection? GSA Today, 23(11), 4-10. https://doi.org/10.1130/GSATG178A.1

Stamm, J. F., Hendricks, R. R., Sawyer, J. F., Mahan, S. A., Zaprowski, B. J., Geibel, N. M., \& Azzolimi, D. C. (2013). Late Quaternary stream piracy and strath terrace formation along the Belle Fourche and lower Cheyenne Rivers, South Dakota and Wyoming. Geomorphology, 197, 10-20. https://doi.org/10.1016/j.geomorph.2013.03.028

Straffin, E. C. (1993). Alluvial terrace development in the southeastern Black Hills of South Dakota [M.S. thesis]: Flagstaff, Northern Arizona University, 91p.

Sugden, D. E. (1976). A case against deep erosion of shields by continental ice sheets. Geology, 4, 580-582. https://doi.org/10.1130/0091-7613(1976)4<580:ACADEO >2.0.CO;2

Thornbury, W. D. (1965). Regional Geomorphology of the United States: John Wiley and Sons, New York, 609 p.

Todd, J. E. (1902). The hydrographic history of South Dakota. Geological Society of America Bulletin, 13, 27-40. https://doi.org/10.1130/GSAB-13-27

United States Geological Survey National Map website: https://viewer.nationalmap.gov/advanced-viewer/

United States Geological Survey South Dakota Water Science Center Black Hills Floods Since 1877. Retrieved from https://sd.water.usgs.gov/projects/FloodHistory/floodhistory.html

Wanless, H. R. (1923). The stratigraphy of the White River beds of South Dakota. Proceedings of the American Philosophical Society, 62, 190-269.

White, W. A. (1972). Deep erosion by continental ice sheets. Geological Society of America Bulletin, 81(4), 1037-1056. https://doi.org/10.1130/0016-7606(1972)83[1037:DEBCIS]2.0.CO;2

Zaprowski, B. J., Evenson, E. B., Pazzaglia, F. J., \& Epstein, J. B. (2001). Knickzone propagation in the Black Hills and northern High Plains: a different perspective on the late Cenozoic exhumation of the Laramide $\begin{array}{llll}\text { Rocky } \quad \text { Mountains. } & \text { Geology, } & \text { 29, }\end{array}$ https://doi.org/10.1130/0091-7613(2001)029b0547:KPITBH>2.0.CO;2

\section{Copyrights}

Copyright for this article is retained by the author(s), with first publication rights granted to the journal.

This is an open-access article distributed under the terms and conditions of the Creative Commons Attribution license (http://creativecommons.org/licenses/by/4.0/). 